\title{
PENERIMAAN ORANGTUA TERHADAP ANAK DENGAN AUTISME DI PUSAT LAYANAN AUTIS (PLA) DAERAH ISTIMEWA YOGYAKARTA
}

\author{
Deby Zulkarnain Rahadian Syah ${ }^{1}$, Puji Sutarjo ${ }^{2}$, Inna Riescananda ${ }^{1}$ \\ ${ }^{1}$ Stikes Jenderal Achmad Yani Yogyakarta, Jalan Ringroad Barat, Ambarketawang, Gamping, Sleman, \\ Yogyakarta. Email: deby.ayani14@gmail.com \\ ${ }^{2}$ Rumah Sakit Jiwa Grhasia Yogyakarta
}

\begin{abstract}
Background: Autism is a developmental disorder in children that affects their social and imaginative lifes. Parents' acceptance on their children's autism will have impact on how they treat their children.

Objective: The aim of this study was to determine the parental acceptance of children with autism in the Autism Services Center (ASC), Yogyakarta.

Methods: This study was a qualitative research with a phenomenological approach. The data collection was conducted by in-depth interviews with three informans.

Results: All the informants accepted their children's conditions, after getting information about autism. Acceptance of parents indicated their satisfaction with the children's talent. Parents provide facilities to support the children's talents. In addition, the acceptance of parents indicated by the acceptance of the cildren's limitations.

Conclusion: Participants accepted their children's conditions, talents and limitations.
\end{abstract}

Keywords: Autism, Parental Acceptance.

\section{PENDAHULUAN}

Autisme adalah gangguan perkembangan pada masa kanak-kanak dengan manifestasi interaksi sosial dan imajinatif yang rusak. ${ }^{(1)}$ Autisme disebabkan oleh beberapa faktor, yaitu faktor genetik, pendarahan pada awal kehamilan, obat-obatan yang dikonsumsi pada masa kehamilan, gangguan pernapasan, anemia, infeksi yang mengakibatkan fungsi sel otak terganggu, keracunan logam berat, autoimun. ${ }^{(2)}$ Anak dengan autisme biasanya melakukan gerakan berulang-ulang (stereotipik) tanpa tujuan, membenturkan kepala dengan letupan emosi, tidak mampu melakukan kontak mata, dan jika mampu melakukan kontak mata akan disertai dengan sikap agresif dan letupan emosi. ${ }^{(3)}$
World Health Organization (WHO) (2013) menyatakan bahwa prevalensi penderita autisme di dunia sebanyak 1 dari 160 orang, terhitung lebih dari 7,6 juta jiwa yang hidup dengan autisme. ${ }^{(4)}$ Sementara prevalensi autis di Yogyakarta sebanyak 12 tiap 10.000 anak. ${ }^{(5)}$

Orangtua yang kurang menerima kehadiran anaknya karena hal tertentu akan memengaruhi cara orangtua memperlakukan anaknya. $^{(6)}$ Orangtua yang menerima biasanya digambarkan sebagai orangtua yang penyayang dan penuh kehangatan, selain itu juga menerima keadaan anaknya dan dirinya sendiri sehingga menjadi lebih bijak dan mampu menjalani hidup yang lebih realistik. ${ }^{(7)}$

Berdasar data dari Dikpora DIY (2015), Indonesia memiliki 34 Pusat Layanan Autis 
(PLA) yang salah satunya berada di DIY, yaitu berada di Sentolo, Kulon Progo, Daerah Istimewa Yogyakarta. ${ }^{(8)}$ Hasil wawancara studi pendahuluan dengan koordinator PLA, orangtua sering mengeluhkan perilaku anak yang terkadang tenang dan terkadang sulit diatur, serta pada saat konsultasi dengan terapis orangtua sering menyembunyikan keadaan anak yang sebenarnya dan kurang menerima keadaan anak, seperti orangtua mengatakan anaknya baik-baik saja, namun saat dilakukan terapi anak tidak menunjukkan sikap yang baik.

Penelitian ini dilakukan bertujuan untuk mengetahui penerimaan orangtua terhadap anak dengan autisme, serta mengetahui penerimaan orangtua terhadap anak dengan autisme dilihat dari aspek kepuasan akan bakat diri anak dan pengakuan keterbatasan anak.

\section{BAHAN DAN CARA PENELITIAN}

Penelitian ini merupakan penelitian kualitatif dengan pendekatan fenomenologi yang dilakukan di PLA DIY pada bulan JuliAgustus 2016. Informan yang digunakan dalam penelitian ini adalah 3 orangtua (ibu) yang memiliki anak dengan autisme dengan menggunakan purposive sampling dengan kriteria informan sebagai berikut: bersedia menjadi informan, ibu kandung dari anak dengan autisme yang melakukan terapi di PLA, dan kooperatif (terbuka). Alat yang digunakan dalam penelitian ini adalah pedoman wawancara.
Peneliti mengumpulkan seluruh orangtua yang sedang menunggu proses terapi anak dengan autisme dan memilih tiga calon informan yang sesuai dengan kriteria. Teknik pengambilan data menggunakan wawancara sesuai dengan pedoman wawancara yang telah dibuat untuk mengetahui penerimaan orangtua, yaitu sikap yang menggambarkan bahwa individu merasa puas akan kualitas dan bakat diri anak serta menyadari atau mengakui keterbatasan anak. Teknik keabsahan data pada penelitian menggunakan teknik triangulasi waktu, yaitu melakukan wawancara kembali pada 3 informan yang sama pada minggu berikutnya. Sementara teknik analisis data yang digunakan adalah reduksi data, display data, kesimpulan, dan verifikasi.

\section{HASIL DAN PEMBAHASAN}

1. Hasil

a. Ketiga informan orangtua telah menerima keadaan anaknya yang menyandang autisme. Informan P1 menyatakan bahwa telah menerima keadaan anaknya yang menderita autisme sejak anaknya belum didiagnosa autisme karena informan P1 berusaha mencari informasi mengenai perilaku-perilaku yang ditunjukkan anaknya adalah perilaku autisme. Informan P2 mengatakan bahwa informan P2 dan suami memiliki penerimaan yang sejalan, karena orangtua merasakan perilaku-perilaku 
anaknya memang berbeda dari anak lainnya. Sementara P3 menerima keadaan anaknya karena bagi informan P3 anak merupakan titipan Tuhan, sehingga informan P3 berharap hal yang terjadi pada anaknya memiliki hikmah yang besar.

b. Kepuasan akan Bakat Diri Anak

Sebagian besar orangtua merasa puas akan bakat diri anaknya ditunjukkan dengan kemampuan informan dalam mengetahui kelebihan atau bakat anak serta antusias informan pada saat diwawancarai mampu menceritakan secara detail. Beberapa bakat anak dari informan tidak sama, hal itu karena setiap individu memiliki kemampuan, minat, dan bakat yang berbeda antara satu dengan lainnya. Adanya kepuasan terhadap kemampuan atau bakat diri anak ditunjukkan dengan tindakan orangtua yang berupaya memberikan fasilitas untuk mengembangkan bakat anaknya.

P1 mengatakan bahwa anaknya suka membaca dan mampu mengoperasikan komputer secara otodidak. Sehingga untuk mendukung dan meningkatkan kemampuan atau kelebihan anaknya yang suka membaca, orangtua bertindak dengan memberi fasilitas membelikan papan tulis dan membantu anak belajar membaca ketika anak sedang tertarik untuk belajar membaca. Sementara untuk mendukung dan meningkatkan kemampuan anaknya yang mampu mengoperasikan komputer orangtua berusaha memfasilitasi anaknya dengan membelikan laptop untuk mengembangkan kemampuannya. P2 mengatakan bahwa anaknya memiliki ketertarikan dalam bidang olahraga fisik, terutama dalam bermain air dan berenang sehingga orangtua bertindak untuk mengajari anak mereka berenang dan merencanakan jadwal renang bersama secara rutin. Sementara P3 belum mampu melihat kelebihan atau bakat anak karena anak belum menunjukkan hal yang menonjol, meski begitu informan tetap berusaha mencari tahu.

c. Pengakuan Keterbatasan Anak

Seluruh orangtua mau mengakui kekurangan atau keterbatasan anaknya yang menunjukkan ciri dari autisme yang diderita anaknya, yaitu P1 yang mengatakan bahwa keterbatasan atau perilaku autisme pada anaknya adalah keterlambatan berbicara, tidak adanya kontak mata, tidak mampu berkomunikasi, perilaku hiperaktif, cuek dengan lingkungan sekitar, ketidakmampuan anak dalam memahami kalimat. P2 mengatakan bahwa keterbatasan atau perilaku autisme tidak merespon pada panggilan, kesulitan dalam diajak 
berinteraksi dan komunikasi, keterlambatan bicara, perilaku cuek pada sekitar, serta kemampuan mengurus diri atau kemandirian yang masih kurang. Sementara P3 mengatakan bahwa keterbatasan atau perilaku autisme yang ditunjukkan anaknya adalah tidak merespon pada panggilan, kemampuan berkomunikasi yang terbatas, serta kemandirian yang tidak sesuai dengan usianya. Hal tersebut masing-masing mulai terlihat pada anak dari informan $\mathrm{P} 1$ pada umur 0 bulan dan anak pada informan P2, P3 pada umur kurang dari 2 tahun.

\section{Pembahasan}

a. Menerima Anak dengan Autisme

Hasil wawancara dengan informan P1, P2, dan P3 menunjukkan bahwa orangtua telah menerima keadaan anaknya yang menderita autisme. Kedua pasangan orangtua dapat menerima kondisi anaknya. ${ }^{(9)}$

Penerimaan orangtua yaitu suatu efek psikologis dan perilaku dari orangtua pada anaknya seperti rasa saya, kelekatan, kepedulian, dukungan, dan pengasuhan yang dapat dirasakan dan diekspresikan oleh orangtua. ${ }^{(10)} \mathrm{Hal}$ tersebut ditunjukkan oleh informan P1 dan P2 yang menyatakan bahwa telah menerima keadaan anaknya karena telah mengetahui perkembangan anaknya yang tidak seperti anak lainnya sebelum anaknya didiagnosa.
Sementara pernyataan informan P3 bahwa anak merupakan titipan Tuhan sehingga informan berharap ada hikmah yang besar.

Proses penerimaan orangtua ketiga informan terhadap anak sesuai dengan teori Kubler Ross yang menyatakan bahwa proses penerimaan merupakan puncak dari penyangkalan, marah, tawar menawar, dan depresi. ${ }^{(11)}$ Informan P1 dan P2 menyatakan bahwa saat anak didiagnosa autisme, informan merasa kaget dan sedih, namun informan tidak terlarut dengan keadaan tersebut. Ketiga informan memilih untuk mencari informasi mengenai autisme dan hal-hal yang harus dilakukan, sehingga informan mampu menerima anaknya yang menderita autisme.

b. Kepuasan akan Bakat Diri Anak

Menurut Hurlock 1987 menyatakan bahwa penerimaan orangtua ditandai dengan perhatian besar dan kasih sayang, sehingga orangtua yang menerima akan memperhatikan perkembangan kemampuan anak dan memperhitungkan minat. ${ }^{(12)}$ Pernyataan tersebut relavan dengan hasil dari analisa data didapatkan bahwa informan P1 dan P2 mengetahui kelebihan dan bakat yang dimiliki anaknya yang dapat disimpulkan sebagai rasa puas, yaitu $\mathrm{P} 1$ yang menyatakan bahwa anaknya memiliki 
minat akademik dalam membaca dan mampu mengoperasikan komputer secara otodidak, P2 menyatakan bahwa anaknya memiliki ketertarikan dalam olahraga fisik, terutama berenang, sementara informan P3 masih belum melihat kelebihan atau bakat anaknya karena anak belum menunjukkan sesuatu yang menonjol, meski begitu informan P3 tetap berusaha untuk mencari tau hal itu.

c. Pengakuan Keterbatasan Anak

Perilaku autisme pada anak merupakan kekurangan anak yang dianggap sebagai kendala atau kesulitan terbesar adalah sulit memahami kata, sehingga orangtua mengalami kesulitan dalam berkomunikasi dengan anak. P1, P2, dan P3 mengatakan bahwa kekurangan atau keterbatasan anak yang menunjukkan perilaku autisme adalah tidak adanya kontak mata, tidak merespon saat dipanggil, serta ketidakpedulian atau sikap cuek anak akan hal-hal yang terjadi di sekitar dan stimulasi yang diberikan oleh sekitar, hal ini sesuai dengan hasil penelitian Klin, dkk (2002) yang menunjukkan hasil bahwa gangguan interaksi sosial anak dengan autisme ditandai dengan ketidaktertarikan pada situasi sosial sehingga anak sulit menikmati hubungan sosial yang bermakna dengan orang lain. ${ }^{(1)}$
Ketiga informan menunjukkan perilaku autisme masing-masing pada P1 umur 0 bulan, pada P2 sebelum umur 2 tahun, dan pada P3 sebelum umur 2 tahun yang berarti bahwa ketiga anak informan termasuk dalam klasifikasi autisme infantil. Hal itu sesuai dengan klasifikasi menurut YPAC (2011) bahwa autisme infantil digunakan untuk menyebut penyandang autisme yang kelainannya sudah nampak sejak lahir. ${ }^{(2)}$

\section{KESIMPULAN DAN SARAN}

1. Kesimpulan

Seluruh informan di Pusat Layanan Autisme (PLA) Daerah Istimewa Yogyakarta telah menerima keadaan anaknya yang mengalami autisme. Penerimaan yang baik orangtua terhadap anak dengan autisme ditunjukkan dengan adanya kepuasan akan bakat diri anak dan upaya memberikan fasilitas untuk pengembangannya. Selain itu, penerimaan orangtua ditunjukkan dengan adanya pengakuan akan keterbatasan anak yang menunjukkan perilaku autisme yang ditunjukkan sebelum anak berusia 2 tahun yang biasa disebut sebagai autisme infantil.

2. Saran

\section{a. Bagi PLA}

Penelitian ini diharapkan dapat dijadikan pertimbangan untuk meningkatkan mutu pelayanan dengan 


\begin{abstract}
diadakannya konsultasi dengan psikolog untuk orangtua dalam menghadapi anak autis.

b. Bagi Peneliti Selanjutnya
\end{abstract}

Penelitian ini dapat digunakan sebagai dasar untuk penelitian selanjutnya dengan variabel penerimaan orangtua menggunakan teknik yang berbeda.

c. Bagi Orangtua

Orangtua diharapkan dapat meningkatkan kerja sama dan konsultasi dengan PLA.

d. Bagi Perawat

Diharapkan perawat dapat bekerja sama dengan orangtua untuk memberikan asuhan keperawatan kepada anak dengan autisme secara komprehensif (meluas), yaitu asuhan keperawatan terhadap anak, orangtua, dan lingkungan.

\section{KEPUSTAKAAN}

1. Pieter, H.Z., Janiwarti, B., Saragih, M. Pengantar Psikopatologi untuk Keperawatan. Jakarta: Kencana Prenada Media Group. 2011.

2. Yayasan Pembinaan Anak Cacat (YPAC). Buku Penanganan dan Pendidikan Autis di YPAC. $2011 . \quad$ http://ypacnasional.org/download/BUKU\%20PENAN GANAN\%20dan\%20Pendidikan\%20Autis \%20di\%20YPAC\%207April.pdf didownload pada: 3 Mei 2016 pukul: 11.30 WIB.
3. Nurdin, A.E. Tumbuh Kembang Perilaku Manusia. Jakarta: EGC. 2011.

4. WHO.Autism Spectrum Disorders. 2016. http://www.who.int/mediacentre/factsheets /autism-spectrum-disorders/en/. diakses pada: 18 Mei 2016. Pukul: 13.15 WIB

5. Rahmawati, S., \& Julia, M. Hubungan antara Pola Konsumsi Gluten dan Kasein dengan Skor CARS (Childhood Autism Rating Scale) pada Anak ASD (Autistic Spectrum Disorder). Jurnal Gizi Klinik Indonesia, 3 (1), 86-92. 2006. http://www.ijcn.or.id/download/Vol3No1Juli 2006/Rahmawati.pdf, diakses pada: 26 Mei 2016. Pukul: 18.30 WIB.

6. Siswanto, H. Pendidikan Kesehatan Anak Usia Dini. Jakarta: EGC. 2010.

7. Suwaji, I. Hubungan Antara Penerimaan Orang Tua dan Konsep Diri Dengan Motivasi Berprestasi Pada Anak Slowlearner. Persona, Jurnal Psikologi Indonesia. Vol. 3. No. 03. Hal: 283-88. $2014 . \quad$ http://jurnal.untagsby.ac.id/index.php/persona/article/view/4 17/381, diunduh pada 26 Januari 2016. Pukul 10.30 WIB.

8. Dikpora DIY. Pusat Layanan Autis Kulon Progo Tangani 56 Anak. 2015. http://www.pendidikan-

diy.go.id/dinas_v4/?view=v_berita\&id_sub =3986, diakses pada: 18 Mei 2016. Pukul: 12.05 WIB.

9. Agustikasari,D.Penerimaan Orangtua Kandung pada Anaknya yang Penyandang Autis. 2016. 
http://eprints.ums.ac.id/41841/1/NASKAH

\%20PUBLIKASI.pdf, diunduh pada: 23

Mei 2016 pukul: 12.42 WIB.

10. Purnomo, P. M. Penerimaan Orangtua terhadap Anak Penderita Autis di Surakarta. 2015. http://eprints.ums.ac.id/34270/1/02.\%20N ASKAH\%20PUBLIKASI.pdf, diunduh pada 10 Juni 2016 pukul: 19.07 WIB.

11. Asyanti, S., dan Wardhani, R. S. P. Penerimaan Keluarga Pasien Skizofrenia yang Menjalani Rawat Inap di RSJ. 2015. https://publikasiilmiah.ums.ac.id/bitstrea m/handle/11617/6535/24-

Rizka\%20Stevi\%20Pura\%20Wardhani.p df? sequence $=1$ \&isAllowed $=y, \quad$ diakses pada: 26 Mei 2016. Pukul 10.00 WIB.

12. Khasanah, U. Penerimaan Orangtua pada Anak yang Menyandang Tunarungu (Doctoral dissertation, UIN Sunan Ampel Surabaya). 2011. http://digilib.uinsby.ac.id/9296/, diunduh pada: 3 Mei 2016. Pukul: 10. 59 WIB. 